$\begin{array}{ll}\text { environmental } & \text { sfam } \\ \text { microbiology } & \text { sfonmental } \\ \text { microbiology reports } & \text { sfm }\end{array}$

\title{
Oasis Desert Farming Selects Environment-Specific Date Palm Root Endophytic Communities and Cultivable Bacteria that Promote Resistance to Drought
}

\begin{tabular}{|r|l|}
\hline Journal: & Environmental Microbiology and Environmental Microbiology Reports \\
\hline Manuscript ID: & Draft \\
\hline Manuscript Type: & EMIR - Brief report \\
\hline Dournal: & Environmental Microbiology Reports \\
\hline Complete List of Authors: & $\begin{array}{l}\text { Cherif, Hanene } \\
\text { Marasco, Ramona; KAUST, BESE } \\
\text { Rolli, Eleonora; Università degli Studi di Milano, DiSTAM } \\
\text { Ferjani, Raoudha } \\
\text { Fusi, Marco; KAUST, BESE } \\
\text { Soussi, Asma } \\
\text { Mapelli, Francesca } \\
\text { Blilou, Ikram; Wageningen UR, } \\
\text { Borin, Sara; Università degli Studi di Milano, Distam; } \\
\text { Boudabous, Abdellatif } \\
\text { Cherif, Ameur } \\
\text { Daffonchio, Daniele; KAUST, BESE; University of Milano, DISTAM } \\
\text { Ouzari, Hadda }\end{array}$ \\
\hline \hline Keywords: & $\begin{array}{l}\text { microbial ecology, microbe:higher organism interactions, microbial } \\
\text { communities }\end{array}$ \\
\hline \multirow{2}{*}{\begin{tabular}{l} 
\\
\hline
\end{tabular}} \\
\hline
\end{tabular}

\section{SCHOLARONE ${ }^{m}$}

Manuscripts 
1 Oasis Desert Farming Selects Environment-Specific Date Palm Root Endophytic Communities 2 and Cultivable Bacteria that Promote Resistance to Drought

4 Hanene Cherif $^{1^{*}}$, Ramona Marasco ${ }^{2 *}$, Eleonora Rolli ${ }^{3 *}$, Raoudha Ferjani ${ }^{1}$, Marco Fusi ${ }^{2}$, Asma Soussi ${ }^{2}$,

5 Francesca Mapelli ${ }^{3}$, Ikram Blilou ${ }^{4}$, Sara Borin ${ }^{3}$, Abdellatif Boudabous ${ }^{1}$, Ameur Cherif ${ }^{5}$, Daniele

6 Daffonchio $^{2,3 \#}$ and Hadda Ouzari ${ }^{1 \#}$

7

$8{ }^{1}$ Laboratoire de Microbiologie et Biomolécules Actives, Département de Biologie, Faculté des 9 Sciences de Tunis, Campus Universitaire, 2092 Tunis, Tunisia.

$10{ }^{2}$ Biological and Environmental Sciences and Engineering Division, King Abdullah University of 11 Science and Technology, Thuwal 23955-6900, Kingdom of Saudi Arabia.

$12{ }^{3}$ Department of Food Environmental and Nutritional Sciences, Università degli Studi di Milano, 13 20133, Milano, Italy.

$14{ }^{4}$ Plant Developmental Biology, Wageningen UR, Wageningen, The Netherlands.

$15 \quad{ }^{5}$ Laboratory BVBGR, ISBST, University of Manouba, La Manouba 2010, Tunisia.

$17 *$ Equal contribution

18 \# Authors for correspondence: Daniele Daffonchio, daniele.daffonchio@kaust.edu.sa; Hadda Ouzari, 19 imene.ouzari@fst.rnu.tn

21 Running title: Oasis Palm Endophytes Promote Drought Resistance 
Oases are desert-farming agro-ecosystems, where date palm (Phoenix dactylifera L.) plays a keystone role in offsetting the effects of drought and maintaining a suitable microclimate for agriculture. At present, abundance, diversity and plant growth promotion (PGP) of date palm root-associated bacteria remain unknown. Considering the environmental pressure determined by the water scarcity in the desert environments, we hypothesized that bacteria associated with date palm roots improve plant resistance to drought. Here, the ecology of date palm root endophytes from oases in the Tunisian Sahara was studied with emphasis on their capacity to promote growth under drought. Endophytic communities segregated along a north-south gradient in correlation with geo-climatic parameters. Screening of 120 endophytes indicated that date palm roots select for bacteria with multiple PGP traits. Bacteria rapidly crosscolonised the root tissues of different species of plants, including the original Tunisian date palm cultivar, Saudi Arabian cultivars and Arabidopsis. Selected endophytes significantly increased the biomass of date palms exposed to repeated drought stress periods during a ninemonths greenhouse experiment. Overall, results indicate that date palm roots shape endophytic communities that are capable to promote plant growth under drought conditions,

40 thereby contributing an essential ecological service to the entire oasis ecosystem. 
47 Desert oases are fragile ecosystems, where environmental conditions are milder than those in the surrounding desert ensuring fertility and allowing desert farming (Mekki et al., 2013). Date palm (Phoenix dactylifera L.) is a keystone species in the oasis ecosystem because it conditions the oasis microclimate by controlling air temperature, humidity and soil-water dynamics, making it suitable for agriculture (de Grenade et al., 2013). However, date palm cultivation is threatened by low rainfall, high temperatures, water resources often high in salt content, and high incidence of pests (Downer, 2004; El-Juhani et al., 2010; Barreveld, 1993).

Plant-associated microbes (rhizobacteria and endophytes) benefit the host by positively affecting paedogenesis and nutrient availability, stimulating growth, suppressing diseases, inducing abiotic stress tolerance and influencing crop yield and quality (Mapelli et al., 2012, Berg et al., 2013; Puente et al., 2004). Changes in the structure of plant-associated bacterial communities towards the selection of assemblages that are metabolically and physiologically adapted to abiotic stress, improve the resistance to stressors such as drought by providing different services to plants: (i) production of exopolysaccharides that protect roots from mechanical stress determined by dry soil compactness; (ii) promotion of osmolyte accumulation that contribute to reduce cell dehydration; (iii) enzymatic and non-enzymatic alleviation of oxidative stress; and (iv) synthesis of hormone-like substances that modulate root development and hormone homeostasis (Ahmad et al., 2008; Balloi et al., 2010; Berard et al., 2012; de Zelicourt et al., 2013: Lau et al., 2012).

Despite evidence that endophytic bacteria are capable of supporting plant growth under stress (Rolli et al., 2015), no data exist on the date palm endophytic bacteria and their role in the protection against drought conditions.

Here, we aim to assess the ecology, rhizocompetence and capability of date palm endophytic bacteria to support plant resistance to drought. We will address the following questions: (i) are geo-climatic factors involved in shaping the endophytic community structure in date palm root?, (ii) do endophytes 
71 on date palm roots have plant growth promoting (PGP) functional traits linked to drought resistance?,

72 (iii) are cultivable endophytes rhizocompetent and do they present cross-colonisation capacities in different plants? and (iv) do date palm root endophytes favour plant tolerance to drought stress?

Results

Inter-oases beta-diversity of the endophytic bacterial community in the root of date palm.

The oases selected for this study (Supporting Figure 1A) were private agriculture farms, characterized by a traditional management: old date palm tree plantations, organic fertilization and irrigation by submersion using deep aquifer fossil water. The oases located along north-south aridity transect were characterized by poorly fertile soils, with loess soils in the northern oases (BD-16, BD-B, and BD-C) and sandy-silt soil in the southern ones (BD-1, BD-5, BD-8 and BD-9).

Similar numbers of 16S rRNA gene copies of endophytic bacteria were measured by quantitative Real Time PCR in the root tissues of date palms from seven Tunisian desert oases (PERMANOVA; $\mathrm{df}=6$, $20 ; \mathrm{F}=1.1 ; \mathrm{p}=0.4 ;$ Supporting Figure 1B).

Multiple-band PCR-DGGE profiles of the 16S rRNA gene were observed in the root tissues, demonstrating discrete endophytic bacterial communities inhabiting the date palm root tissues along the examined north-south aridity transect (Supporting Figure 2). Principal coordinate analysis (PCoA) of PCR-DGGE gel-band profiles explained $81.5 \%$ of the total variability and indicated a north-south segregation pattern of bacterial communities relative to the latitudinal position of the oases with respect to the Chott El Jerid saline system (Fig. 1A); these results were confirmed by canonical analysis of principal coordinates (CAP), where a clear separation between northern-southern oases is evident (Fig. 1B). Endophytic bacterial communities segregated between oases located to the North (BD-16, BD-B and BD-C) and South (BD-1, BD-5, BD-8 and BD-9) of the Chott El Jerid as supported by PERMANOVA Pair Wise test (PERMANOVA, df $=1,20 ; \mathrm{F}=20.19 ; \mathrm{p}<0.001$; 
96 Supporting Table 2). Among the environmental factors examined (Supporting Table 1), a marginal test revealed that latitude, longitude, altitude, temperature and rainfall were statistically significant driving forces determining the structure of root-associated bacterial communities (Table 1A). However, latitude and temperature proved to be the dominant geo-climatic variables shaping the structure of endophytic bacterial communities (Table 1B). We assessed the linkage of the environmental factors through Multiple Correspondence Analysis that showed they were related each other whit the only exception for the minimum rainfall (Supporting Figure 3).

\section{PGP functionality of cultivable endophytic bacteria associated with date palm roots.}

A total of 120 bacterial strains were isolated from the root tissues of date palms cultivated in the oases sampled. Isolates were assigned to five phyla, Proteobacteria $(76 \%)$, consisting of Beta- $(6 \%)$ and Gamma-Proteobacteria (70\%), Actinobacteria (17\%), Firmicutes (6\%) and Bacteroidetes (1\%) (Fig. 2A), consistent with the cultivation-independent approach (Supporting Table 3). Phylogenetic analysis performed on the isolates showed that species belonged to 11 bacterial genera (Fig. 2B), where Pseudomonas were the most common, representing $27 \%$ of the collection $(35 \%$ in the southern oases and $16 \%$ in the northern oases).

The 28 different genotypes identified following dereplication of the collection by internal transcribed spacer-PCR (ITS-PCR) fingerprinting were characterized for PGP activities in vitro (Fig. 2C). Potentially beneficial strains, according to their PGP scores indicating multiple PGP and biocontrol traits and resistances to different abiotic stresses, were recovered from all the date palm roots samples. While none of the isolates displayed all the assayed PGP traits, 13 strains presented 12 or more and 15 strains ranged between 8 and 11 PGP traits. All isolates showed potential adaptation to unfavourable environmental conditions typical of arid soils through halotolerance ( 26 strains grew in media with $5 \%$ $\mathrm{NaCl}$ added) and resistance to low-water availability (28 strains) and variable temperature ranges (10 strains). None of the strains grew at $50^{\circ} \mathrm{C}$ and only 6 strains tolerated $10 \% \mathrm{NaCl}$ in the growth medium. PGP potential properties, such as those related to nutrient provision (phosphate solubilisation 
122 and siderophore release) and auxin synthesis were equally distributed among isolates. Exopolymers

123 (EPS) production was primarily presented by Pseudomonas strains. Seventy five percent of the strains

124 were active against both Botrytis cinerea and Aspergillus niger.

125 Two strains with contrasting PGP scores (Fig. 2C), Pseudomonas frederickbergensis E102 and

126 Pseudomonas brassicacearum E141 strains, were selected for further studies on the rhizocompetence and the in vivo PGP potential on date palm.

In vitro root adherence and co-colonisation assay on date palm and Arabidopsis thaliana.

Date palm root colonization by strain E141 was studied using a $g f p$-labelled mutant. Colonisation was observed to persist after $72 \mathrm{~h}$ (Fig. 3A). Co-colonisation competition assay with an exogenous bacterial competitor demonstrated a selective colonisation capacity of strain E141. After $72 \mathrm{~h}$ exposure to $d s R E D$-labelled E. coli and $g f p$-labelled E141, only cells of the latter were detected on date palm root rhizoplane (Fig. 3B). Root colonization by the $g f p$-labelled E141 strain was also observed on Arabidopsis root. Along time course experiments, microscopic observations of Arabidopsis roots exposed for $1 \mathrm{~h}$ to the $g f p$-labelled $P$. brassicacearum strain E141 revealed green fluorescent cells along the primary root (Supporting Figure 4A). After $3 \mathrm{~h}$ of exposure, the organisation of bacterial cell microcolonies was observed both on primary roots and root hairs (Supporting Figure 4B). Five hours after exposure to the strain, the expected arrangement of $g f p$-labelled cell clusters continued to adhere to the rhizoplane (Supporting Figure 4C). The gfp-labelled E141 strain had considerably colonised the primary root after 24 (Supporting Figure 4D) and 48 hours, while no cells of the $d s R E D$-labelled $E$. coli were observed on the root after $48 \mathrm{~h}$ from the initial bacterization (Fig. 3C). The experiment confirmed the ability of strain E141 to establish on the root system of a plant species other than its original host. Fluorescent $g f p$-labelled E141 cells were detected in abundance on the rhizoplane of both the studied plant root systems, and were also visible in longitudinal-sections of the roots, suggesting its ability to penetrate root tissues (Fig. 3B and C). 
147 In addition, closer quantitative evaluation showed that both Pseudomonas spp. strains E102 and E141

148 efficiently colonised the roots of all three date palm cultivars (Deglet Nour, Safawy and Sofry) at high 149 density (Fig. 3D). The strain E102 maintained a constant population density at about $10^{4} \mathrm{CFU} \mathrm{g}^{-1}$ of 150 tissue on all three cultivars. Similar values were observed with E141-treated roots, with the exception

151 of the Sofry cultivar that had a density of $10^{3} \mathrm{CFU} \mathrm{g}^{-1}$ on root tissue. No kanamycin-resistant isolates 152 other than the strains E102 and E141 were obtained from inoculated plants or non-inoculated control plants, indicating that no contamination by spontaneous kanamycin-resistant bacteria occurred.

154

Date palm growth promotion under controlled drought stress.

Strains E102 and E141 were tested for their in vivo PGP potential during a nine months-long growth experiment that included ten successive periods of induced water stress. During the experiment field capacity was maintained at $50 \%$ while during the water stress periods it was decreased down to 15 $20 \%$ by interrupting irrigation (Fig. 4 A). Bacteria-treated date palm plantlets had significantly more fresh aerial and root biomasses than non-inoculated plants (Fig. 4B and C, Supporting Table 4 and 5). Both strains increased fresh biomass of date palm shoot and root between $25-30 \%$ and $20-23 \%$, respectively (Fig. 4B and C). Dry biomass (Fig. 4B and C) and number of leaves (Fig. 4D) confirmed that bacterial inoculation significantly increased plant growth (Supporting Table 4). No statistical differences were observed for root or shoot length (Fig. 4E, Supporting Table 4 and 5).

\section{Discussion}

The environmental conditions of the oases were found to influence the diversity of the endophytic bacterial communities in the date palm roots, but not the cell abundance, differently from what was observed in the rhizosphere (Ferjani et al., 2014). The selection of endophytic bacteria by root tissues is a complex process controlled by several factors including, the plant physiological features, the soil 
172 geochemical characteristics, the agriculture management practices and the geoclimatic conditions 173 (Angel et al., 2010; Bachar et al., 2010; Berg and Smalla, 2009; Chaparro et al., 2013; Ding et al., 174 2013; Hardoim et al., 2008; Schlaeppi et al., 2014). We found that latitude and temperature influenced beta-diversity of root-associated endophytic bacteria, such that they could clearly be separated into two groups, those South and those North of the Chott El Jerid saline lake in southern Tunisia. Results support the conjecture that beta-diversity of date palm endophytic communities varies along a northsouth environmental gradient and indicate that PCR-DGGE of 16S rRNA gene was able to detect such variations in beta-diversity. Even though PCR-DGGE is not anymore adequate for assessing alphadiversity in comparison with next generation sequencing (NGS), several recent studies have shown that community fingerprinting techniques, including PCR-DGGE, are still useful for analysing betadiversity, where they support the same conclusions as NGS techniques (Cleary et al. 2012; Gobet et al., 2014; Van Dorst et al., 2014).

To improve the effectiveness of isolation of root endophytes from the inner part of date palm root, we have initially tested a root-peeling approach (Sessitsch et al., 2002). However, since we were not able to obtain intact root cores, we have adopted a surface sterilization procedures with bleach and ethanol treatments (Sun et al., 2008) that did not affect the root structure. Cultivable date palm endophytic bacteria were primarily from the class Gammaproteobacteria. Gammaproteobacteria-rich root tissues have been documented in other arboreal plants growing in arid regions such as grapevines (Marasco et al., 2013a), banana trees (Souza et al., 2013) as well as trees grown in conventional environments (Lodewyckx et al., 2002; Taghavi et al., 2009). Gammaproteobacteria of the genus Halomonas were observed only in Ksar Ghilane, the southern-most oasis examined in this study. The majority of soil in arid and semiarid areas is salt-affected, particularly in oases, where salt accumulation is caused by a combination of factors including poor quality of irrigated water, poor or no drainage, shallow saline water tables, and salinization of soil and groundwater (Marlet et al., 2009). Halomonas strains with PGP properties have previously been observed in association with halophytes such as Salicornia spp. (Argandonña et al., 2005; Jha et al 2012) including those in the same area of the oases studied here (Mapelli et al., 2013). 
199 The most frequent endophytic bacteria among the isolates belonged to the genus Pseudomonas well 200 known for its PGP properties (Ali et al., 2013; Roca et al., 2014). Pseudomonads from the date palm 201 root endosphere were capable to enhance phosphate solubilisation, release siderophores, fix nitrogen, produce phytohormones and ACC deaminase, produce EPS and grow at low water activities in presence of $20 \%$ polyethylene glycol (PEG). These features may support, directly or indirectly, plant growth under drought favouring water uptake (Compant et al., 2010; Daffonchio et al., 2015).

The above-mentioned isolates represent bacterial species capable of forming colonies after 48 hours incubation on agar plates. However, these fast growing bacteria represent a fraction of the root system microbiome (Hardoim et al., 2008). It should be considered that several slow growing bacteria such as many actinobacteria are also an important component of the root system microbiome and they would deserve further studies in the date palm (Sessitsch et al., 2002; Quin et al., 2015).

210 We have demonstrated that date palm roots provide a suitable microenvironment for bacteria with multiple PGP traits. Fully developed metabolic interactions require physical contacts between plants and their endophytes (Brader et al., 2014). Before bacteria can express any PGP traits, endophytes must adhere to the rhizoplane, colonise the root system and finally spread throughout the plant's tissues (Hardoim et al., 2008; Marasco et al., 2013b; Rodriguez-Navarro et al., 2007). The Pseudomonas strains E102 and E141 efficiently cross-colonized different plant species and date palm cultivars, confirming their endophytic lifestyle.

Under drought conditions Deglet Nour date palms treated with Pseudomonas spp. E102 or E141 appeared healthier, with increased fresh and dry biomass of the roots and the whole plant, compared to non-inoculated plants. Because of the increase in plant dry weight rather than in water content, bacteria can be accredited for a capacity of stimulating growth and increasing biomass. Plants with more root biomass can efficiently extract residual soil water during drought-stress periods, favouring overall plant growth as observed in shoot weights. Therefore, in addition to the nutritional and protective effects that have been shown for oil, banana and coconut palms (Andrade et al., 2014;

224 Bakhtiar et al., 2013; Garcia et al., 2012; George et al., 2013; Mia et al., 2010), endophytic bacteria 
225 also help palms cope with water stress and drought, two essential obstacles to desert farming. The

226 versatility of these strains in root colonization, general PGP activities and specific promotion of 227 resistance to drought suggests that such drought-protective activity likely takes place naturally in oasis ecosystems.

\section{Experimental procedures}

231

Study sites and preparation of date palm root tissues.

During March 2010, root samples of date palm (Phoenix dactylifera L. cv. Deglet Nour) were collected from seven different oases located along an aridity-latitude gradient in Tunisia (Supporting figure 1A) characterized by different geo-climatic traits (Supporting Table 1). In each sampling station, the roots of three healthy Deglet Nour date palms of similar age were collected at $40-60 \mathrm{~cm}$ depth, where the root system is most dense and active. All root samples were collected using sterile tools. In the laboratory, the root tissues were immediately surface-sterilized as described by Sun et al. (2008) and the efficacy of the sterilization method was verified by plating the water from the last washing step and by plating pieces of the sterilized root on Trypic Soy Agar (TSA). No colonies were obtained from all the control plates after 10 days incubation at $30^{\circ} \mathrm{C}$. Recovered samples were stored at $-20^{\circ} \mathrm{C}$ for molecular analysis and at $4^{\circ} \mathrm{C}$ for isolation.

DNA extraction, Real Time-PCR and PCR-DGGE analyses.

245 Three grams of surface-sterilised roots were ground in liquid nitrogen using a sterile mortar and pestle to obtain a homogenous root tissue powder. Total DNA was extracted from $1 \mathrm{~g}$ of powdered root tissue using the DNeasy Plant kit (Qiagen), according to the manufacturer's protocol. The DNA was quantified and stored at $-20^{\circ} \mathrm{C}$ until use. 
249 Quantitative Real Time-PCR (q-PCR) was performed on a Chromo4 real-time detector (Bio-Rad) to 250 measure the presence and concentration of bacterial populations in root tissues following the method 251 described in Merlino et al. (2013).

252 Primers 907R and 357F with a GC-clamp were used in this study for the amplification of bacterial 16S 253 rRNA genes (Muyzer et al., 1993). DGGE fingerprint analysis was performed as described in Marasco et al. (2012). The DGGE bands were excised from the gels using a sterile cutter extracted from the gel plug and amplified as reported in Marzorati et al. (2006). Amplification products were sequenced by Macrogen Inc. (South Korea), and sequences were deposited in the GenBank database under accession numbers KM355719 to KM355744. The DGGE band patterns were converted into line plots using Image $\mathrm{J}$ software to generate a matrix of $\mathrm{x} / \mathrm{y}$ values (Schneider et al., 2012). Statistical analyses of the data are reported in the Supporting Material under the heading "Statistical Analysis".

Isolation, identification and in vitro PGP activities of cultivable endophytes.

One gram of sterilised root from each sampling station was ground in phosphate buffer saline (10 mM $\mathrm{K}_{2} \mathrm{HPO}_{4}, 10 \mathrm{mM} \mathrm{KH} \mathrm{PO}_{4}, 0.14 \mathrm{M} \mathrm{NaCl}$ ) using a sterile mortar and pestle. The suspension was diluted in 10-fold series and plated onto TSA medium. After incubation at $30^{\circ} \mathrm{C}$ for $48 \mathrm{~h}$, fast-growing bacterial colonies representing different morphotypes were selected and spread three times on the original medium. A total of 120 purified isolates were frozen in $25 \%$ glycerol at $-80^{\circ} \mathrm{C}$ until use.

DNA was extracted from isolates by boiling lysis as described by Marasco et al. (2012). Isolates were dereplicated using the ITS-PCR fingerprinting protocol (Daffonchio et al., 1998). Representative isolates from each genotype were identified by partial sequencing of the 16S rRNA gene at Macrogen

270 Inc. (South Korea) after PCR amplification according to Marasco et al. (2012). Sequences were deposited in the GenBank database under accession numbers KM355745 to KM355772. mineral phosphate solubilisation, nitrogen-fixation activity, EPS and ammonia production, protease 
274 activity and tolerance to drought, salt and temperature variation as described in the Supporting 275 Methods 1.

In vivo recolonization experiment of date palm and Arabidopsis root system.

278 The isolates in the collection were transformed with the pHM2-gfp plasmid (Favia et al., 2007). Stable

279 transformants were obtained with P. frederikbergensis E102 and P. brassicacearum E141 strains as

280

281

282

283

284

285 described in the Supporting Methods 2.

The $g f p$-labelled strain E141 was selected for colonisation experiments on date palm and Arabidopsis following the protocol described in the Supporting Methods 3. A co-colonisation competition assay was performed using $g f p$-labelled E141 and $d s R E D$-labelled E. coli, as described in the Supporting Method 4. At time intervals, bacterized roots of date palm and Arabidopsis seedlings were analysed by confocal laser-scanning microscopes (Leica TCSNT) with Leica Confocal Software, using BP530/30 GFP (excitation at $488 \mathrm{~nm}$ ) and LP590 TRITC filters (excitation length at $568 \mathrm{~nm}$ ). For some experiments (as explained in the figure legends) a Zeiss LSM 710 Upright Confocal Microscope has been used with GFP and Propidium Iodide (PI) lasers and Bright Field light (BF) and the software ZEN2009.

Quantification of the colonization of date palm roots by strains E102 and E141 were performed by selective plating of the strains transformed with plasmid pHM2-gfp as described in Supporting Methods 5.

The ability of Pseudomonas sp. to promote date palm growth in vivo under drought stress.

Date palm seeds (Phoenix dactylifera cv. Deglet Nour) were soaked in water for $48 \mathrm{~h}$ to soften the mesocarp, sterilized with $90 \%$ ethanol for $2 \mathrm{~min}$ and then $1 \%$ sodium hypochlorite for $15 \min$ followed by three rinses in sterile distilled water. Surface-sterilized seeds were sown in a pot containing $3 \mathrm{Kg}$ of sterilized soil mixture (3:1 soil to sand). The soil mixture was sterilized by the 
299 tyndallisation method: three cycles of sterilization at $100^{\circ} \mathrm{C}$ for $60 \mathrm{~min}$ were alternated with overnight 300 incubation at $30^{\circ} \mathrm{C}$. After tyndallisation, $1 \mathrm{~g}$ of the soil mixture was serially diluted and spread on a 301 TSA petri dish to evaluate the CFU. After $48 \mathrm{~h}$ at $30^{\circ} \mathrm{C}$, the $\mathrm{CFU} \mathrm{g}{ }^{-1}$ of mixed soil had bacterial counts $302<10^{1}$. Seeds were coated once with the bacterial suspension strains E102 and E141 at a concentration 303 of $10^{8}$ cells $\mathrm{g}^{-1}$ of soil; non-inoculated seeds were watered with sterile tap water. Seeds were 304 maintained at $30^{\circ} \mathrm{C}$ for 1 week and after germination the pots were transferred to a growth chamber 305 with $\sim 100 \mu \mathrm{mol}$ photons $\mathrm{m}^{-2} \mathrm{~s}$ of light for $12 \mathrm{~h}$ during the day; the average temperature is reported in 306 Fig. 4A. The in vivo experiment continued for approximately 9 months $(281 \mathrm{~d})$. Date palm plantlets experienced a variable degree of controlled water stress reported as a percentage of field capacity (Fig. 4A). After $281 \mathrm{~d}$ shoot and root fresh weight, dry weight and length and number of leaves were measured on each of the 19 replicate plants per treatment. Statistical analyses of the data are reported in the Supporting Material under the heading "Statistical Analysis".

\section{Acknowledgements}

The authors declare an absence of competing interests. This research was supported by the EU project BIODESERT (European Community's Seventh Framework Programme CSA-SA REGPOT-2008-2 under grant agreement no. 245746), King Abdullah University of Science and Technology (baseline research funds to D.D.) and the BIOGESTECA project (no. 15083/RCC 'Fondo per la promozione di accordi istituzionali', Regione Lombardia, Italy). ER and FM acknowledge support by Università degli Studi di Milano, DeFENS, the European Social Fund (FSE) and Regione Lombardia (contract 'Dote Ricerca'). 
Ahmad, F., Ahmad, I., and Khan, M.S. (2008) Screening of free-living rhizospheric bacteria for their multiple plant growth promoting activities. Microbiol Res 163: 173-181.

Ali, S.Z., Sandhya, V., Rao, L.V. (2013). Isolation and characterization of drought-tolerant ACC deaminase and exopolysaccharide-producing fluorescent Pseudomonas sp. Ann Microbiol 64: 493-502.

Andrade, L.F., de Souza, G.L.O.D., Nietsche, S., Xavier, A.A., Costa, M.R., Cardoso, A.M.S., et al., (2014) Analysis of the abilities of endophytic bacteria associated with banana tree roots to promote plant growth. J Microbiol 52: 27-34.

Angel, R., Soares, M.I., Ungar, E.D., and Gillor O. (2010) Biogeography of soil archaea and bacteria along a steep precipitation gradient. ISME J 4: 553-563.

Argandonña, M., Fernaàndez-Carazo, R., Llamas, I., Martínez-Checa, F., Caba, J.M., Quesada, E., and Moral, A. (2005) The moderately halophilic bacterium Halomonas maura is a free-living diazotroph. FEMS Microbiol Lett 244: 69-74.

Bachar, A., Al-Ashhab, A., Soares, M.I.M., Sklarz, M.Y., Angel, R., Ungar, E.D., and Gillor, O. (2010). Soil microbial abundance and diversity along a low precipitation gradient. Microb Ecol 60: $453-461$.

Bakhtiar, Y., Yahya, S., Sumaryono, W., Sinaga, M.S., and Budi, S.W. (2013) Adaptation of oil palm seedlings inoculated with arbuscular mycorrhizal fungi and mycorrhizal endosymbiotic bacteria Bacillus subtilis B10 towards biotic stress of pathogen Ganoderma boninense. Path Microbiol 6: $157-164$.

Balloi, A., Rolli, E., Marasco, R., Mapelli, F., Tamagnini, I., Cappitelli, F., et al. (2010) The role of microorganisms in bioremediation and phytoremediation of polluted and stressed soils. Agrochimica 54: 353-369.

Barreveld, W.H. (1993) Date palm products. Agricultural services bulletin no. 101. Rome, Italy: FAO. 
348 Berard, A., Ben Sassi, M., Renault, P., and Gros, R. (2012) Severe drought-induced community 349 tolerance to heat wave. An experimental study on soil microbial processes. J Soils Sediments 12: $513-518$.

Berg, G., and Smalla, K. (2009) Plant species and soil type cooperatively shape the structure and function of microbial communities in the rhizosphere. FEMS Microbiol Ecol 68: 1-13.

Berg, G., Zachow, C., Müller, H., Philipps, J., and Tilcher, R. (2013) Next-generation bio-products sowing the seeds of success for sustainable agriculture. Agronomy 3: 648-656.

Brader, G., Compant, S., Mitter, B., Trognitz, F., and Sessitsch, A. (2014) Metabolic potential of endophytic bacteria. Curr Opin Biotechnol 27: 30-37.

Chaparro, J.M., Badri, D.V., Bakker, M.G., Sugiyama, A., Manter, D.K., and Vivanco, J.M. (2013) Root exudation of phytochemicals in Arabidopsis follows specific patterns that are developmentally programmed and correlate with soil microbial functions. PLoS One, 8: e55731.

Cleary, D.F.R., Smalla, K., Mendonca-Hagler L.C.S., Gomes, N.C.M. (2012) Assessment of variation in bacterial composition among microhabitats in a mangrove environment using DGGE fingerprints and barcoded pyrosequencing. PlosONE 7: e29380.

Compant, S., Van Der Heijden, M.G.A., and Sessitsch, A. (2010) Climate change effects on beneficial plant-microorganism interactions. FEMS Microbiol Ecol 73: 197-214.

Daffonchio, D., Borin, S., Frova, G., Manachini, P.L., and Sorlini, C. (1998) PCR fingerprinting of whole genomes: the spacers between the $16 \mathrm{~S}$ and $23 \mathrm{~S}$ rRNA genes and of intergenic tRNA gene regions reveal a different intraspecific genomic variability of Bacillus cereus and Bacillus licheniformis. Int J Syst Bacteriol 1: 107-116.

Daffonchio, D., Hirt, H., and Berg, G. (2015) Plant-microbe interaction and water management in arid and saline soils. In: Principles of Plant-Microbe Interactions, (Ed. B. Lugtenberg) Springer International Publishing, pp 265-276. 
372 De Grenade, R. ( 2013) Date palm as a keystone species in Baja California peninsula, Mexico oases. J Arid Env 94: 59-69

De Zelicourt, A., Al-Yousif, M., and Hirt, H. (2013) Rhizosphere microbes as essential partners for plant stress tolerance. Mol Plant 6: 242-245.

Ding, G.C., Piceno, Y.M., Heuer, H., Weinert, N., Dohrmann, A.B., and Carrillo, A. (2013) Changes of soil bacterial diversity as a consequence of agricultural land use in a semi-arid ecosystem. PLoS One 8: e59497.

Downer, J. (2004) Palm tree management. Part I: Selecting the right palms. Landscape Notes 18: 4.

El-Juhany, L.I. (2010) Degradation of date palm trees and date production in Arab countries: causes and potential rehabilitation. Aust J Basic Appl Sci 4: 3998-4010.

Favia, G., Ricci, I., Damiani, C., Raddadi, N., Crotti, E., Marzorati, M., et al., (2007) Bacteria of the genus Asaia stably associate with Anopheles stephensi, an Asian malarial mosquito vector. Proc Natl Acad Sci USA, 104: 9047-9051.

Ferjani, R., Marasco, R., Rolli, E., Cherif, H., Cherif, A., Gtari, M., et al., (2014) The date palm tree rhizosphere is a niche for plant growth promoting bacteria in the oasis ecosystem. BioMed Res Int accepted for publication, in press.

García, A., Jimena, A., Martínez, M.M., and Gutiérrez, V. (2012) Effect of phosphate-solubilizing bacteria and compost on the nutritional characteristics of the oil palm crop (Elaeis guineensis Jacq.) in Casanare, Colombia. Agronom Colomb 30: 274-281.

George, P., Gupta, A., Gopal, M., Thomas, L., and Thomas, G.V. (2013) Multifarious beneficial traits and plant growth promoting potential of Serratia marcescens KiSII and Enterobacter sp. RNF 267 isolated from the rhizosphere of coconut palms (Cocos nucifera L.). World J Microbiol Biotechnol 29: 109-117. 
Gobet, A., Boetius, A., Ramette, A. (2014) Ecological coherence of diversity patterns derived from classical fingerprinting and Next Generation Sequencing techniques. Environ Microbiol 16: 2672-2681.

Hardoim, P.R., van Overbeek, L.S., and Elsas, J.D.V. (2008) Properties of bacterial endophytes and their proposed role in plant growth. Trends Microbiol 16: 463-471.

Jha, B., Gontia, I., and Hartmann, A. (2012) The roots of the halophyte Salicornia brachiata are a source of new halotolerant diazotrophic bacteria with plant growth-promoting potential. Plant Soil 356: 265-277.

Lau, J.A., and Lennon J.E. (2011) Evolutionary ecology of plant-microbe interactions: Soil microbial structure alters selection on plant traits. New Phytologist 192: 215-224.

Lodewyckx, C., Vangronsveld, J., Porteous, F., Moore, E.R., Taghavi, S., Mezgeay, M., and der Lelie, D.V. (2002) Endophytic bacteria and their potential applications. Cr Rev Plant Sci 21: 583-606.

Mapelli, F., Marasco, R., Balloi, A., Rolli, E., Cappitelli, F., Daffonchio, D., and Borin, S. (2012) Mineral-microbe interactions: biotechnological potential of bioweathering. J Biotechnol 157: 473-481.

Mapelli, F., Marasco, R., Rolli, E., Barbato, M., Cherif, H., Guesmi, A., et al., (2013) Potential for plant growth promotion of Rhizobacteria associated with Salicornia growing in Tunisian hypersaline soils. BioMed Res Int 2013: 248078.

Marasco R, Rolli E, Ettoumi B, Vigani, G., Mapelli, F., Borin, S., et al. (2012) A drought resistancepromoting microbiome is selected by root system under desert farming. PLoS One 7: e48479.

Marasco, R., Rolli, E., Fusi, M., Cherif, A., Abou-Hadid, A., El-Bahairy, U., et al., (2013a) Plant growth promotion potential is equally represented in diverse grapevine root-associated bacterial communities from different biopedoclimatic environments. BioMed Res Int 2013: 491091. 
Marasco, R., Rolli, E., Vigani, G., Borin, S., Sorlini, C., Ouzari, H., et al., (2013b) Are droughtresistance promoting bacteria cross-compatible with different plant models? Plant Signal Behav 10: e26741.

Marlet, S., Bouksila, F., and Bahri, A. (2009) Water and salt balance at irrigation scheme scale: a comprehensive approach for salinity assessment in a Saharan oasis. Agric Water Manag 96: $1311-1322$

Marzorati, M., Borin, S., Brusetti, L., Daffonchio, D., Marsili, C., Carpani, G., and de Ferra, F. (2006) Response of 1,2-dichloroethane-adapted microbial communities to ex-situ biostimulation of polluted groundwater. Biodegradation 17: 41-56.

Mekki, I., Jacob, F., Marlet, S., and Ghazouani, W. (2013) Management of groundwater resources in relation to oasis sustainability: The case of the Nefzawa region in Tunisia. $J$ Environ Manag 121: 142-151.

Merlino, G., Rizzi, A., Schievano, A., Tenca, A., Scaglia, B., Oberti, R., et al., (2013) Microbial community structure and dynamics in two-stage single-stage thermophilic anaerobic digestion of mixed swine slurry and market bio-waste. Water Res 47: 1983-1995.

Mia, M.A., Shamsuddin, Z.H., Wahab, Z., and Marziah, M. (2010) Rhizobacteria as bioenhancer and biofertilizer for growth and yield of banana Musa spp. cv. 'Berangan'. Sci Hortic 126: 80-87.

Muyzer, G., De Waal, E.C., and Uitterlinden, A.G. (1993) Profiling of complex microbial populations by denaturing gradient gel electrophoresis analysis of polymerase chain reaction-amplified genes coding for 16S rRNA. Appl Environ Microbiol 59: 695-700.

Puente M.E., Li, C.Y., Bashan, Y. (2004). Microbial populations and activities in the rhizoplane of rock-weathering desert plants. Plant Biol 6: 643-50.

Qin, S., Miao, Q., Feng, W.-W., Wang, Y., Zhu, X., Xing, K., and Jiang, J.H. (2015). Biodiversity and plant growth promoting traits of culturable endophytic actinobacteria associated with Jatropha curcas L. growing in Panxi dry-hot valley soil. Appl Soil Ecol 93: 47-55. 
443 Roca, A., Pizarro-Tobías, P., Udaondo, Z., Fernández, M., Matilla, M.A., Molina-Henares, M.A., 444 Molina, L., Segura, A., Duque E., and Ramos J.L. (2014) Analysis of the plant growth445 promoting properties encoded by the genome of the rhizobacterium Pseudomonas putida BIRD-

Rodríguez-Navarro, D.N., Dardanelli, M.S., and Ruíz-Saínz, J.E. (2007). Attachment of bacteria to the roots of higher plants. FEMS Microbiol Lett 272: 127-136.

Rolli, E., Marasco, M., Vigani, G., Ettoumi, B., Mapelli, F., Deangelis, M.L., et al., (2015) Improved

Schlaeppi, K., Dombrowski, N., Oter, R.G., van Themaat, E.V.L., and Schulze-Lefert, P. (2014)

Sun, L., Qiu, F., Zhang, X., Dai, X., Dong, X., Song, W. (2008) Endophytic bacterial diversity in rice (Oryza sativa L.) roots estimated by 16S rDNA sequence analysis. Microb Ecol 55: 415-424. 
465 Taghavi, S., Garafola, C., Monchy, S., Newman, L., Hoffman, A., Weyens, N., et al., (2009) Genome 466 survey and characterization of endophytic bacteria exhibiting a beneficial effect on growth and 467 development of poplar trees. Appl Environ Microbiol 75: 748-757.

468 Van Dorst, J., Bissett, A., Palmer, A.S., Brown, M., Snape, I., Stark, J.S., et al., (2014) Community 469 fingerprinting in a sequencing world. FEMS Microbiol Ecol 89: 316-330.

470

471 
Table 1. Environmental factors shaping the structure of date palm root endophytic bacterial

communities from oases in southern Tunisia. DistLM analysis was performed on individuate geoclimate variables influencing the structure of the bacterial community associated with date palm root tissues. Geo-climatic variables tested included latitude (Lat N), longitude (Long E), altitude (Alt); minimum temperature ( $\mathrm{T}$ min), maximum temperature ( $\mathrm{T}$ max), minimum rainfall (Rainfall min) and maximum rainfall (Rainfall max). (A) The marginal test considers each geo-climatic variable and its contribution to explaining the total variability. (B) Sequential test to explain the total variation from variables. $\mathrm{F}=$ statistic $\mathrm{F} ; \mathrm{p}=$ probability (statistically significant variables are shown in bold, $\mathrm{p}<0.05$ ); cumulative variation explained by the listed variables; Res $\mathrm{df}=$ residual degrees of freedom.

(A) Marginal test

\begin{tabular}{lccc}
\hline Variables & $\mathrm{F}$ & $\mathrm{P}$ & Prop \\
\hline Lat N & $\mathbf{1 6 . 2 5 6}$ & $\mathbf{0 . 0 0 0 1}$ & $\mathbf{0 . 4 6}$ \\
Long E & $\mathbf{1 1 . 2 1 8}$ & $\mathbf{0 . 0 0 0 1}$ & $\mathbf{0 . 3 7}$ \\
Alt (m) & $\mathbf{3 . 8 3 5 4}$ & $\mathbf{0 . 0 2 0 4}$ & $\mathbf{0 . 1 7}$ \\
T min $\left({ }^{\circ} \mathrm{C}\right)$ & $\mathbf{8 . 0 2 9 5}$ & $\mathbf{0 . 0 0 0 8}$ & $\mathbf{0 . 3 0}$ \\
T max $\left({ }^{\circ} \mathrm{C}\right)$ & 1.9707 & 0.1239 & 0.09 \\
Rainfall min (mm) & $\mathbf{7 . 9 8 7 2}$ & $\mathbf{0 . 0 0 0 7}$ & $\mathbf{0 . 3 0}$ \\
Rainfall max (mm) & $\mathbf{3 . 6 7 2 5}$ & $\mathbf{0 . 0 2 3 0}$ & $\mathbf{0 . 1 6}$ \\
\hline
\end{tabular}

485

(B) Sequential test

\begin{tabular}{lcccccc}
\hline Variables & AIC & F & P & Prop & Cumul & Res df \\
\hline + Lat N & & & & & & \\
\hline
\end{tabular}




\begin{tabular}{lcccccc}
+ Long E & 95.781 & 1.5973 & 0.1725 & 0.04393 & 0.50501 & 18 \\
+ Alt $(\mathrm{m})$ & 97.382 & 0.32608 & 0.8771 & 0.00932 & 0.51432 & 17 \\
+ T min $\left({ }^{\circ} \mathbf{C}\right)$ & $\mathbf{9 4 . 8 5 6}$ & $\mathbf{3 . 8 4 8 5}$ & $\mathbf{0 . 0 1 0 2}$ & $\mathbf{0 . 0 9 4 1 7}$ & $\mathbf{0 . 6 0 8 4 9}$ & $\mathbf{1 6}$ \\
+ T max $\left({ }^{\circ} \mathbf{C}\right)$ & $\mathbf{9 3 . 3 4 9}$ & $\mathbf{2 . 7 2 6 5}$ & $\mathbf{0 . 0 3 6 3}$ & $\mathbf{0 . 0 6 0 2 2}$ & $\mathbf{0 . 6 6 8 7 1}$ & $\mathbf{1 5}$ \\
+ Rainfall min $(\mathrm{mm})$ & 92.706 & 1.8776 & 0.1068 & 0.03918 & 0.70789 & 14 \\
+ Rainfall max $(\mathrm{mm})$ & 92.706 & 0 & 1 & 0.00000 & 0.70789 & 14 \\
\hline
\end{tabular}


Figure 1. Analysis of the bacterial community structure associated with date palm root tissues in different oases of Tunisia. (A) Principal coordinate analysis represents the structural diversity of endophytic bacterial communities associated with date palm root tissues. The endophytic communities of date palm roots from the northern (black symbols) and southern (grey symbols) oases compared to the Chott El Jerid saline lake exhibit two different groupings that explain $81.5 \%$ of the total variation. (B) The canonical analysis of principal coordinates confirms the separation between northern (black circles) and southern (grey circles) oases.

Figure 2. Diversity and PGP potential of date palm root-associated cultivable endophytic bacteria. Phylogenetic allocation of the isolates from date palm root tissues at class (A) and genus (B) number of PGP potential abilities exhibited by each strain. Abiotic stress resists. $=$ abiotic stress resistance; Bioc. $=$ biocontrol potential; $\mathrm{P}$ Sol. $=$ inorganic phosphate solubilization; Sid. $=$ siderophore production; $\mathrm{N}$ fix. $=$ nitrogen fixation; $\mathrm{EPS}=$ exopolymers release; IAA $=$ auxin production; Amm. = ammonia production; Prot. $=$ protease activity; $\mathrm{ACCd}=\mathrm{ACC}$ deaminase activity; $\mathrm{PEG}=$ polyethylene glycol. The strains marked in grey are those used for the in vivo date palm experiment.

Figure 3. Rhizocompetence and root recolonization ability of date palm root endophytic bacteria on different plant models. Colonization of date palm root after $72 \mathrm{~h}$ by a $g f p$-labelled E141 strain alone (A) or supplied together with a dsRED-labelled E. coli (B). Arabidospis thaliana roots after $48 \mathrm{~h}$ exposure to a $g f p$-labelled E141 strain together with a dsRED-labelled $E$. coli (C). The scale bars correspond to $100 \mu \mathrm{m}$ in (A) and (C) and $10 \mu \mathrm{m}$ in (C). The $g f p$ (panels A-C) and dsRED (panels B and C) fluorescences are visible in green and red, respectively. Images were obtained with a Zeiss 
511 (panels A) or a Leica (panels B and C) confocal microscope (see Experimental Procedures). (D)

512 Reisolation experiments showing the ability of both $P$. brassicacearum E141 and $P$.

513 frederiksbergensis E102 to actively colonize root tissues of different date palm cultivars including the

514 original Tunisian cultivar (Deglet Nour) from which the strains were isolated and two Saudi Arabian

515 cultivars (Safawy and Sofry). CFU g ${ }^{-1}$ are expressed as mean $\pm \mathrm{sd}$.

516

517 Figure 4. Date palm root endophytic bacteria promote the growth of date palms exposed to

518 drought. (A) Levels of controlled drought stress during a 9-months period of date palm growth.

519 Controlled drought periods were induced by interrupting irrigation for periods of time ranging

520 between 6 and $12 \mathrm{~d}$. Field capacity is indicated in grey; actual temperature in the greenhouse is shown

521 by a black line; annual min (blue line) and max (red line) temperatures in the Ksar Ghilane oasis at the

522 same time as the greenhouse experiment. Date palm growth promotion after a 9-months period of

523 fluctuating water stress following the initial inoculation with two strains ( $P$. brassicacearum E141 and

$524 P$. frederiksbergensis E102) isolated from date palm roots sampled in the Ksar Ghilane oasis. Plant

525 biomass after 9-months growth, expressed as mean of shoot (B) and root (C) fresh and dry weights \pm

526 standard error; number of leaves (D) and root and shoot length (E) \pm standard errors. The data

527 (averages, standard deviations and number of plants are reported in Supplementary Table 4) were

528 statistically analysed through a PERMANOVA (Supplementary Table 5); different letters represent

529 statistically significant differences $(\mathrm{p}<0.05)$ for each parameter. 


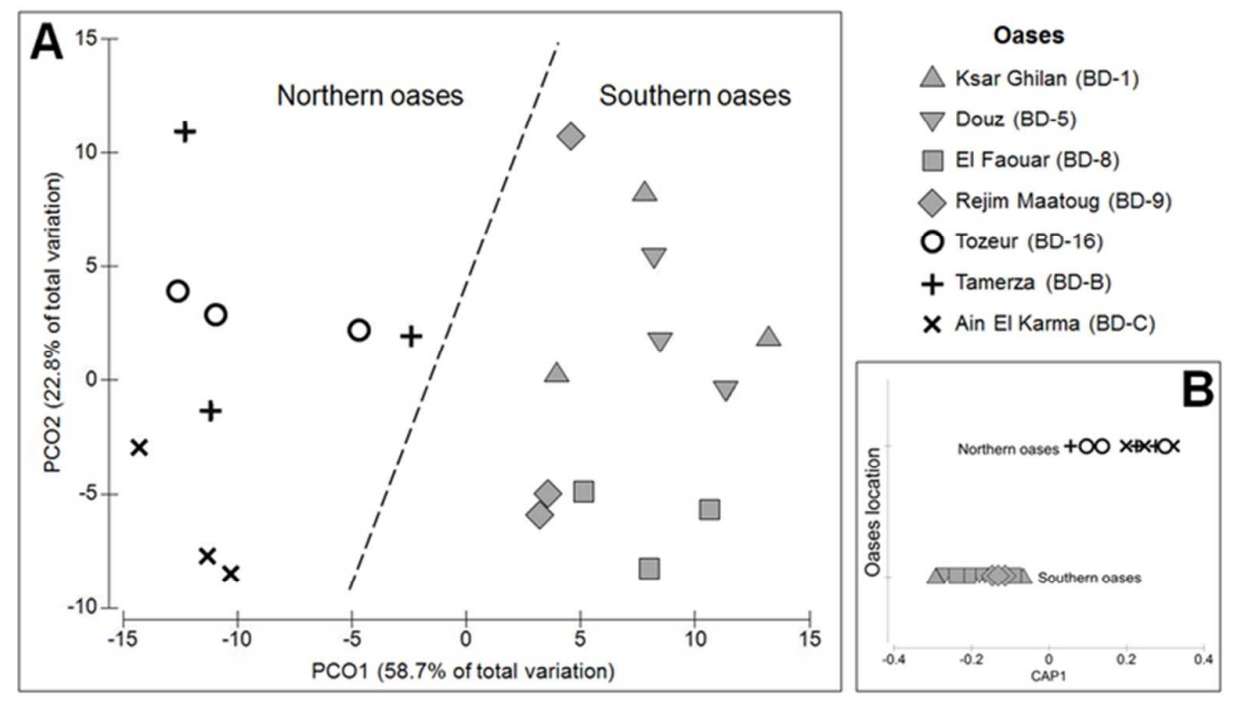

Figure 1. Analysis of the bacterial community structure associated with date palm root tissues in different oases of Tunisia. (A) Principal coordinate analysis represents the structural diversity of endophytic bacterial communities associated with date palm root tissues. The endophytic communities of date palm roots from the northern (black symbols) and southern (grey symbols) oases compared to the Chott El Jerid saline lake exhibit two different groupings that explain $81.5 \%$ of the total variation. (B) The canonical analysis of principal coordinates confirms the separation between northern (black circles) and southern (grey circles) oases.

$62 \times 35 \mathrm{~mm}(300 \times 300 \mathrm{DPI})$ 

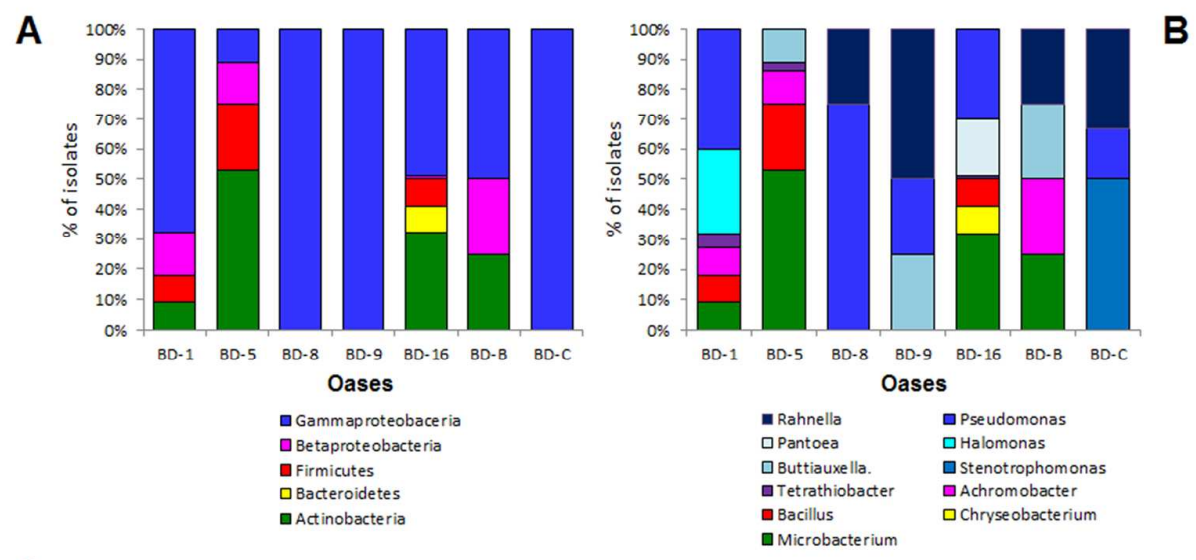

C

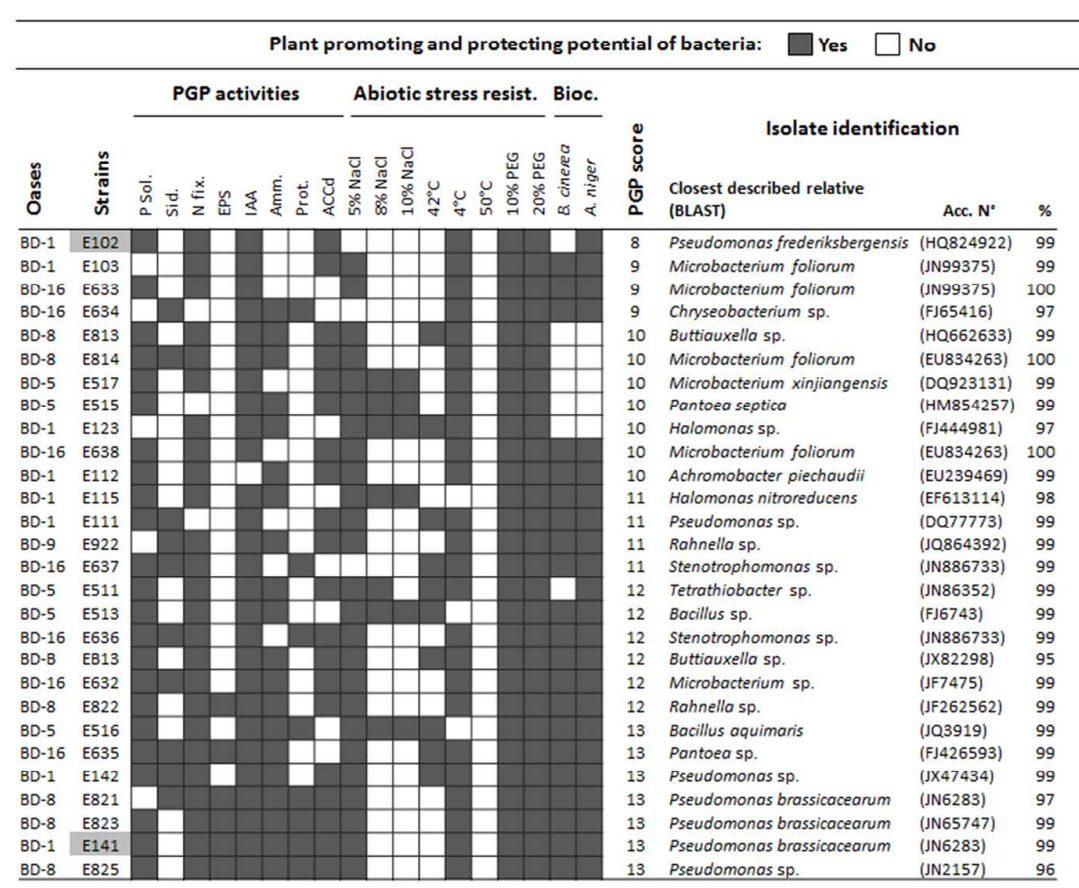

Figure 2. Diversity and PGP potential of date palm root-associated cultivable endophytic bacteria. Phylogenetic allocation of the isolates from date palm root tissues at class (A) and genus (B) levels. (C) PGP potential of the isolates is indicated as a PGP score, determined by the sum of the number of PGP potential abilities exhibited by each strain. Abiotic stress resists. = abiotic stress resistance; Bioc. = biocontrol potential; $\mathrm{P}$ Sol. = inorganic phosphate solubilization; Sid. = siderophore production; $\mathrm{N}$ fix. = nitrogen fixation; $\mathrm{EPS}=$ exopolymers release; IAA = auxin production; Amm. = ammonia production; Prot. = protease activity; ACCd = ACC deaminase activity; PEG = polyethylene glycol. The strains marked in grey are those used for the in vivo date palm experiment.

$200 \times 237 \mathrm{~mm}(300 \times 300 \mathrm{DPI})$ 


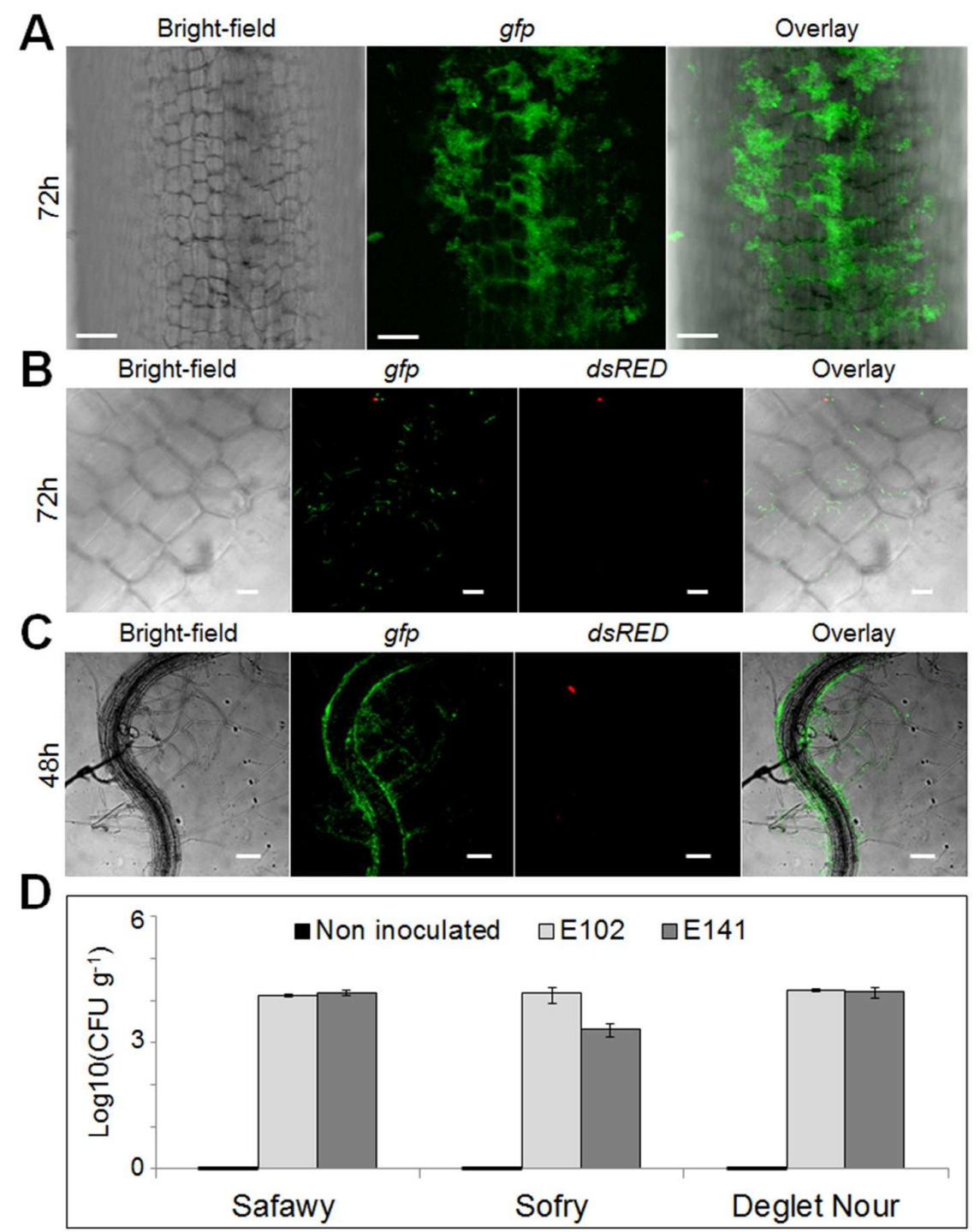

Figure 3. Rhizocompetence and root recolonization ability of date palm root endophytic bacteria on different plant models. Colonization of date palm root after $72 \mathrm{~h}$ by a gfp-labelled E141 strain alone (A) or supplied together with a dsRED-labelled E. coli (B). Arabidospis thaliana roots after $48 \mathrm{~h}$ exposure to a gfp-labelled E141 strain together with a dsRED-labelled E. coli (C). The scale bars correspond to $100 \mu \mathrm{m}$ in (A) and (C) and $10 \mu \mathrm{m}$ in (C). The gfp (panels $A-C$ ) and dsRED (panels $B$ and $C$ ) fluorescences are visible in green and red, respectively. Images were obtained with a Zeiss (panels A) or a Leica (panels B and C) confocal microscope (see Experimental Procedures). (D) Reisolation experiments showing the ability of both P. brassicacearum E141 and P. frederiksbergensis E102 to actively colonize root tissues of different date palm cultivars including the original Tunisian cultivar (Deglet Nour) from which the strains were isolated and two Saudi Arabian cultivars (Safawy and Sofry). CFU g-1 are expressed as mean \pm sd. $141 \times 181 \mathrm{~mm}(300 \times 300 \mathrm{DPI})$ 

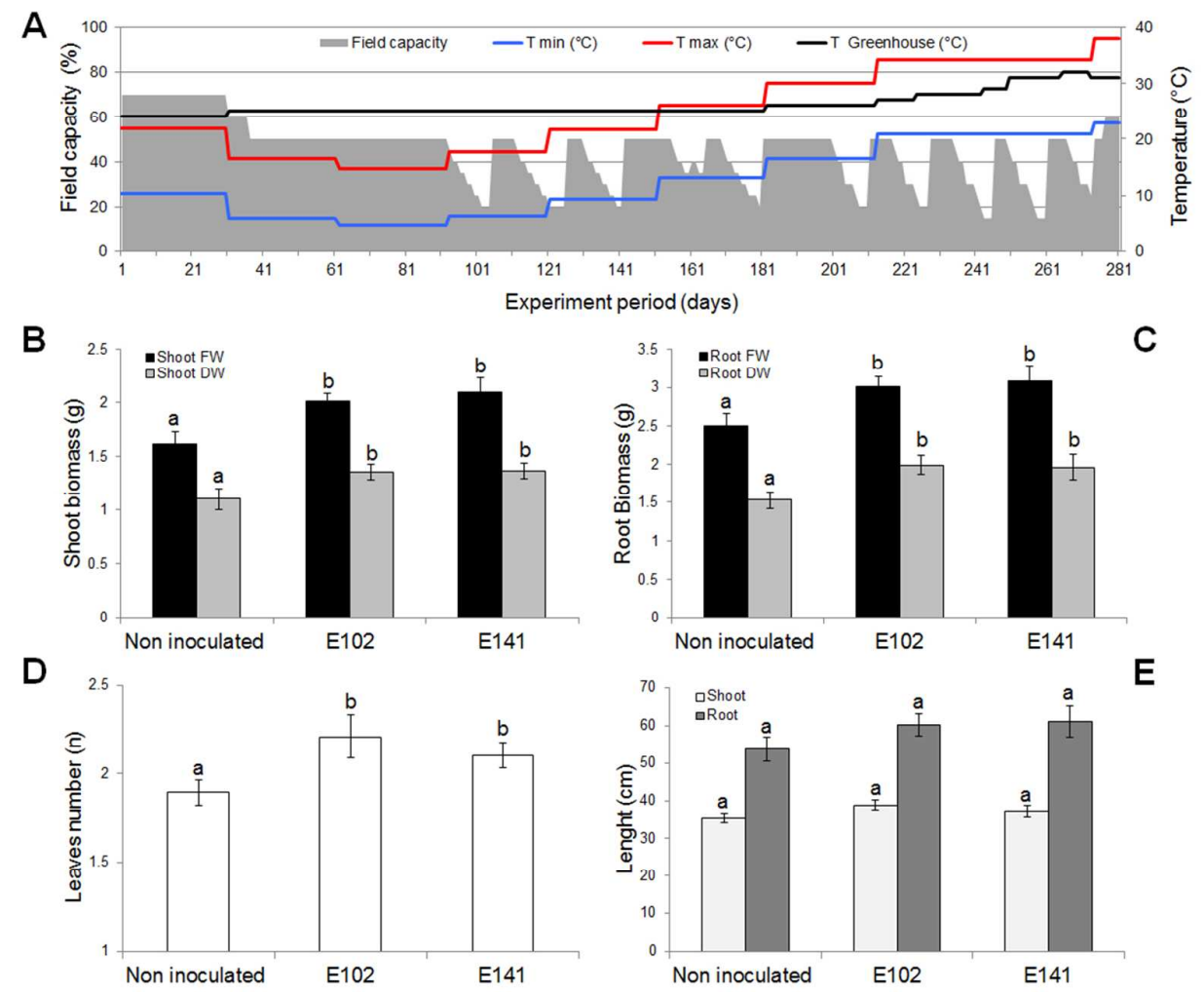

Figure 4. Date palm root endophytic bacteria promote the growth of date palms exposed to drought. (A) Levels of controlled drought stress during a 9-months period of date palm growth. Controlled drought periods were induced by interrupting irrigation for periods of time ranging between 6 and $12 \mathrm{~d}$. Field capacity is indicated in grey; actual temperature in the greenhouse is shown by a black line; annual min (blue line) and max (red line) temperatures in the Ksar Ghilane oasis at the same time as the greenhouse experiment. Date palm growth promotion after a 9-months period of fluctuating water stress following the initial inoculation with two strains (P. brassicacearum E141 and P. frederiksbergensis E102) isolated from date palm roots sampled in the Ksar Ghilane oasis. Plant biomass after 9-months growth, expressed as mean of shoot (B) and root (C) fresh and dry weights \pm standard error; number of leaves (D) and root and shoot length $(E) \pm$ standard errors. The data (averages, standard deviations and number of plants are reported in Supplementary Table 4) were statistically analysed through a PERMANOVA (Supplementary Table 5); different letters represent statistically significant differences $(p<0.05)$ for each parameter. $376 \times 316 \mathrm{~mm}(72 \times 72 \mathrm{DPI})$ 